\title{
Association of Physiological Responses and Root Distribution Patterns to Ratooning Ability and Yield of the Second Ratoon Cane in Sugarcane Elite Clone
}

\author{
Saranya Chumphu ${ }^{1}$, Nuntawoot Jongrungklang ${ }^{1,2}$ and Patcharin Songsri ${ }^{1,2 *}$ \\ 1 Department of Agronomy, Faculty of Agriculture, Khon Kaen University, Khon Kaen 40002, Thailand \\ 2 Northeast Thailand Cane and Sugar Research Center, Faculty of Agriculture, Khon Kaen University, Khon \\ Kaen 40002, Thailand \\ * $\quad$ Correspondence: patcharinso@kku.ac.th Tel.:+66-815-441-325
}

\begin{abstract}
The objective of this study was to determine the association of physiological responses and root distribution patterns on yield of the second ratoon cane and the relationships among these traits. Seventeen sugarcane genotypes were planted in a randomized complete block design with four replications. The second ratoon crop was evaluated for germination percentage, cane yield, SPAD chlorophyll meter reading (SCMR), chlorophyll fluorescence, relative water content (RWC), specific leaf area (SLA) and stomatal conductance. Root length density (RLD) was evaluated by auger method. The root samples were divided into upper soil layer and lowers soil layers to study root distribution patterns. Sugarcane genotypes were significantly different for RLD, germination percentage and cane yield. Root distribution patterns were classified into three groups based on the RLD. High RLD between plants in the upper soil layers at 90 DAH was positively correlated with high germination, whereas high RLD between rows in the lower soil layers at 90 and $270 \mathrm{DAH}$ was associated with high cane yield. RWC at $90 \mathrm{DAH}$ and stomatal conductance at $180 \mathrm{DAH}$ were closely related to germination percentage, whereas chlorophyll fluorescence and stomatal conductance at 180 DAH were closely related to cane yield.
\end{abstract}

Keywords: root length density; ratoon crop; Sacharum spp., varietal selection

\section{Introduction}

Sugarcane is an industrial crop and used mainly as a raw material for sugar production. The byproducts from sugar mill are also used for production of other value-added products such as electricity, veneer, monosodium glutamate and ethanol. Sugarcane is largely grown under rain-fed conditions in arid and semi-arid tropic regions.

Drought stress is the most important factor reducing ratooning ability and sugarcane production in the world. Reduction in cane yield has been estimated at up to 60 percent [1]. Low yield of ratoon crop is mainly due to low and differential ratooning potential of cultivars and suboptimal crop management. Ratoon crop has lower production cost than planted crop by $25-30$ percent [2].

Sugarcane varieties respond differently to drought stress for sprouting, millable canes and commercial cane sugar and ratooning ability [3]. Imprudent of ratooning ability in sugarcane will not be possible if the mechanism underlying the maintenance of ratoon is not fully understood. Therefore, a better understanding on the association of physiological traits of shoot and root in maintaining higher ratooning ability should improve the efficiency of sugarcane production and breeding programs.

Root is an important plant part that takes up nutrients and water for growth and yield of crops. Sugarcane can develop new root system within three days after harvest to replace the old root system. New roots emerged from the basal nodes of young shoots over the next several weeks, but, at 7 weeks after harvest, a few new roots emerged from old roots that had been active at the time of harvest [4]. 
Drought reduced root growth in upper soil layers and root growth is shifted toward the lower soil layers to maintain water uptake [5].

In general, root system and physiological traits of shoot may be inter-related, and the developmental stage of root strongly contributes to the total above-ground growth of plants [6]. (Physiological traits related to photosynthesis such PSII photochemical efficiency (Fv/Fm), stomatal conductance, transpiration, SPAD index and water potential were identified as the traits promoting photosynthesis of sugarcane [7-9].

The information on the responses to drought for physiological traits related to germination and yield of different sugarcane genotypes is still lacking. The objective of this study was to determine the association of physiological responses and root distribution patterns on yield of the second ratoon cane and the relationships among these traits. The information obtained in this study will be useful in explaining the association between ratooning ability and root distribution patterns for recommendation of the surrogate traits for improving sugarcane genotypes in breeding programs.

\section{Materials and methods}

\subsection{Experimental design and plant materials}

Seventeen sugarcane genotypes consisting of 14 elite clones (KKU99-02, KK06-419, MPT02-458, UT13, KKU99-01, KKU99-06, KKU99-03, CSB07-219, CSB07-79, TBy28-1211, KK06-501, MPT05-187, UT12 and TBy28-0941) and three check varieties (Kps01-12, KK3 and K88-92) were laid out in a randomized complete block design with four replications at the Faculty of Agriculture, Khon Kean University, Thailand, to evaluate ratooning ability and yield of the second ratoon cane during the growing season 2016.

The cane stalks were cut into single node segments and the single node segments were planted directly in the five-row plots with $8.0 \mathrm{~m}$ long and $1.5 \mathrm{~m}$ distance between rows in November 2014 . The spacing used was $1.5 \mathrm{~m}$ between row and $1.0 \mathrm{~m}$ within row. Data were recorded from 3 middle rows, discarding the plants at the ends of the rows. The planted crop and the first ratoon crop were harvested in 2014 and 2015, respectively. Chemical fertilizer formula 15-15-15 of N-P2 $\mathrm{O}_{5}-\mathrm{KO}_{2}$ (Thai Central Chemical Public Company Limited, Phra Nakhon Si Ayutthaya, Thailand) at the rate of 312. $5 \mathrm{~kg}$./ha was applied to the ratoon crop at two splits. The first split was applied after the first ratoon crop was harvest and the second split was applied at tillering stage (about 4 months after harvest). Weed control was carried out manually at 4 months after harvest of the first ratoon crop.

\subsection{Data collection}

\subsubsection{Meteorological and soil data}

The meteorological data were recorded during January-December 2016. Rainfall, maximum and minimum temperatures were recorded by the weather station at Agronomy field crop, Faculty of Agriculture, Khon Kaen University. The data of soil moisture content data were recorded at 90,180 and 270 days after harvest (DAH) at depth of 0-20, 20-40, 40-60, 60-80 and 80-100 cm. The soil samples were weighed and oven-dried at $105^{\circ} \mathrm{C}$ for 72 hours. Thereafter, the percentage of soil moisture was determined from weights of wet soil and dry soil.

\subsubsection{Germination percentage}

Number of plants was recorded at 60 days after harvest (DAH) of the first ratoon crop, and germination percentage was calculated as follows;

Germination percentage $=\left(\begin{array}{l}\text { Number of stool germination of the second ratoon crop } \\ \text { Nuber of stool harvested of the first ratoon crop }\end{array}\right) \times 100$ 


\subsubsection{Physiological traits}

Physiological traits consisting of specific leaf area (SLA), SPAD chlorophyll meter reading (SCMR), chlorophyll fluorescence, stomatal conductance and relative water content (RWC) were measured at 90, 180 and $270 \mathrm{DAH}$ from the second fully expanded leaf of the main stalk during 9.00-12.00 a.m. Leaf area was measured using LI-3100C Area Meter, LI-COR, inc. Lincoln, Nebraska USA. Leaf samples were oven-dried at $80^{\circ} \mathrm{C}$ for $72 \mathrm{hr}$. or until the weights were constant and the dry weights were measured. SLA was calculated as the ratio between leaf area $\left(\mathrm{cm}^{2}\right)$ and leaf dry weight (g). SPAD chlorophyll meter reading (SCMR) was measured using SPAD chlorophyll meter (SPAD501, Minolta, Tokyo, Japan), at bottom, middle, and tip of the leaf. Chlorophyll fluorescence was measured on intact leaves using Chlorophyll fluorescence (MINI PAM, Heinz Walz GmbH, Germany) at 6.00-8.00 p.m. Stomatal conductance was measured by SC-1 Leaf Porometer (Decagon Devices, inc. WA 99163, USA). Relative water content (RWC) was measured from the weight difference between freshly harvested leaf and water saturated leaf. Leaf samples were imbibed in distilled water for 24 hours. The water saturated leaves were dried with blotting paper to eliminate the excessive water. Leaf saturated weight was then determined. The leaf samples were then ovendried at $80^{\circ} \mathrm{C}$ for 72 hours and leaf dry weight was measured. Then RWC was calculated as follows; $\mathrm{RWC}=\left(\frac{(\text { Leaf fresh weight }- \text { Leaf dry weight })}{\text { (Leaf saturated weight }- \text { Leaf dry weight })}\right) \times 100$

\subsubsection{Root traits}

Root length density (RLD) was measured at 90 and 270 DAH using an auger method. The auger consisted of a coring tube [10] with a diameter of $69 \mathrm{~mm}$. and a length of $1.15 \mathrm{~m}$. The auger was designed to reduce compaction in the inner tube by improving the cutting edge and reducing the tube thickness $[10,11]$. Root samples were collected from two positions including the position between plant at a distance of $25.0 \mathrm{~cm}$ and the position between row at a distance of $75.0 \mathrm{~cm}$. Root samples were taken to a depth of $100 \mathrm{~cm}$ and separated into five layers consisting of $0-20,20-40,40-$ 60, 60-80 and 80-100 cm.

Root samples of each layer were washed manually with tap water to remove soil from the roots. The root samples were then analyzed with the Winrhizo program (Winrhizo Pro (s) V. 2004a, Regent Instruments, Inc) to determine root length. RLD was calculated as the ratio between root length $(\mathrm{cm})$ and soil volume $\left(\mathrm{cm}^{3}\right)$. RLD from the first $(0-20 \mathrm{~cm}$.) and second $(20-40 \mathrm{~cm}$.) layers were combined and defined as a upper soil layer $(0-40 \mathrm{~cm}$.), while the RLD for the deeper layers (third to fifth) were combined to a single $40-100 \mathrm{~cm}$. layer as lower soil layer.

\subsubsection{Yield}

The cane productivity was calculated from the weight of all millable canes per plot and the area occupied by each plot.

\subsection{Statistical analysis}

Data were subjected to analysis of variance (ANOVA) according to a randomized complete block design. Means were separated by least significant difference (LSD) at 0.05 probability level. Simple correlation was used to determine the relationships among physiological traits, ratooning ability and cane yield.

\section{Results and Discussion}

\subsection{Meteorological conditions and soil moisture content}

This experiment was conducted during January to December 2016. Maximum temperature and minimum temperature were 34.0 and $22.6{ }^{\circ} \mathrm{C}$, respectively (Figure 1). Total rainfall during the experimental period was $1,119 \mathrm{~mm}$. Soil moisture contents at 90 (drought period), 180 (recovery period) and $270 \mathrm{DAH}$ were clearly different (Figure 2). At 90 and $180 \mathrm{DAH}$, soil moisture contents in 
top soil were lower than in sub soil (Figure. 2a, 2b). At $270 \mathrm{DAH}$, soil moisture contents in top soil were higher than sub soil (Figure 2c).

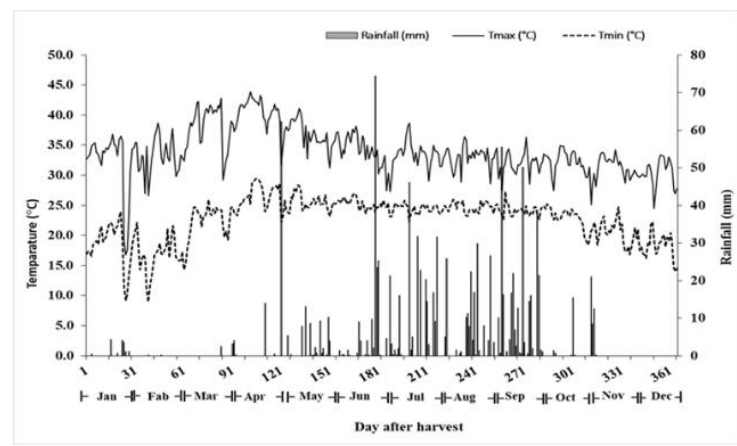

Figure 1. Rainfall (mm), maximum temperature (Tmax) and minimum temperature (Tmin) during January-December 2016.

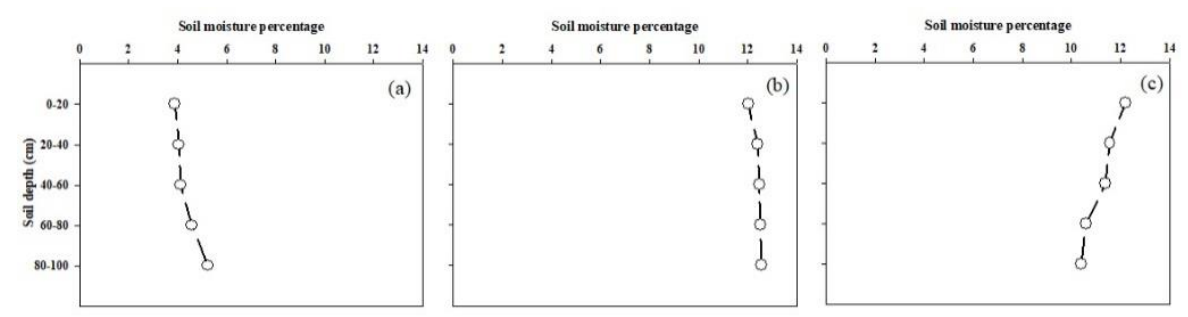

Figure 2. Soil moisture content (\%) at 90 days after harvest (a), 180 days after harvest (b) and 270 days after harvest (c) with drought and recovery periods.

\subsection{Germination and yield}

In Thailand, milling season of sugar industry is from December to early May and it total milling period is about 5-6 months. Sugarcane harvested in the early milling season in December to January will encounter the drought period as the rainfed crop does not receive enough rain in the dry season. Drought can reduce ratooning ability of the crop and ultimately reduce sugarcane production. Breeding of sugarcane for high ratooning ability can help sugarcane growers to have higher income as the sugarcane can be harvested for more years before new planting.

In this study, germination of new plants from harvested plants of second ratoon crop was evaluated at 60 days after harvest (DAH), when the crop was subjected to drought period after harvest, and cane yield was evaluated at $270 \mathrm{DAH}$, when the crop received sufficient rain in the rainy season. The questions are that there are the variations in cane yield and germination percentage in these sugarcane genotypes and whether germination percentage is related to yield.

Sugarcane genotypes were significantly different $(\mathrm{P} \leq 0.01)$ for cane yield and germination percentage compared to the first ratoon crop (Table 1). Cane yields ranging from 50.20 tons/ha in TBy28-0941 to 94.78 tons/ha in KKU99-02 were recorded among sugarcane genotypes, and germination percentages ranged from $35.19 \%$ in KK06-501 to $88.67 \%$ in UT13. The study indicated that wide variations among sugarcane genotypes were observed for cane yield and germination percentage. Germination percentage would be a valuable surrogate trait for cane yield of ratoon crops if the trait is associated with cane yield.

Table 1 Means for cane yield and germination percentage of the second ratoon crop of 17 sugarcane genotypes.

\begin{tabular}{ccc}
\hline Genotype & $\begin{array}{c}\text { Cane yield } \\
\text { (tons/ha) }\end{array}$ & $\begin{array}{c}\text { Germination } \\
\text { percentage (\%) }\end{array}$ \\
\hline KKU99-02 & $94.78^{\mathrm{a}}$ & $71.54^{\mathrm{abc}}$ \\
KK3 & $89.30^{\mathrm{ab}}$ & $81.91^{\mathrm{ab}}$ \\
\hline
\end{tabular}




\begin{tabular}{|c|c|c|}
\hline KK06-419 & $84.14^{\mathrm{abc}}$ & $55.56^{\mathrm{cd}}$ \\
\hline $\begin{array}{c}\text { MPT02- } \\
458\end{array}$ & $80.33^{\mathrm{a}-\mathrm{d}}$ & $63.73^{b c}$ \\
\hline K88-92 & $78.89^{\mathrm{a}-\mathrm{c}}$ & $70.46^{\mathrm{abc}}$ \\
\hline UT13 & $75.55^{\mathrm{a}-\mathrm{f}}$ & $88.67^{a}$ \\
\hline KKU99-01 & $70.66^{a-g}$ & $74.54^{\mathrm{abc}}$ \\
\hline KKU99-06 & $67.59^{\mathrm{b}-\mathrm{g}}$ & $75.58^{\mathrm{abc}}$ \\
\hline KKU99-03 & $64.96^{\mathrm{b}-\mathrm{g}}$ & $79.41^{\mathrm{ab}}$ \\
\hline CSB07-219 & $63.47^{\mathrm{c}-\mathrm{g}}$ & $38.16^{\mathrm{d}}$ \\
\hline CSB07-79 & $58.66^{\mathrm{d}-\mathrm{g}}$ & $76.56^{\mathrm{abc}}$ \\
\hline Kps01-12 & $56.11^{\mathrm{b}-\mathrm{g}}$ & $63.47 \mathrm{bc}$ \\
\hline $\begin{array}{c}\text { TBy28- } \\
1211\end{array}$ & $55.71^{\mathrm{efg}}$ & $70.29 \mathrm{abc}$ \\
\hline KK06-501 & $55.39^{\text {efg }}$ & $35.19^{d}$ \\
\hline $\begin{array}{c}\text { MPT05- } \\
187\end{array}$ & $52.70^{\mathrm{fg}}$ & $60.60^{\mathrm{bc}}$ \\
\hline UT12 & $51.17^{\mathrm{fg}}$ & $68.99 \mathrm{abc}$ \\
\hline $\begin{array}{c}\text { TBy28- } \\
0941\end{array}$ & $50.2^{\mathrm{g}}$ & $64.35^{\mathrm{bc}}$ \\
\hline Mean & 67.63 & 67.00 \\
\hline F-test & $* *$ & $* *$ \\
\hline
\end{tabular}

** significant at $\mathrm{p} \leq 0.01$. Mean in the same column followed by the same letters are not significant different at $\mathrm{P} \leq 0.05$ by LSD

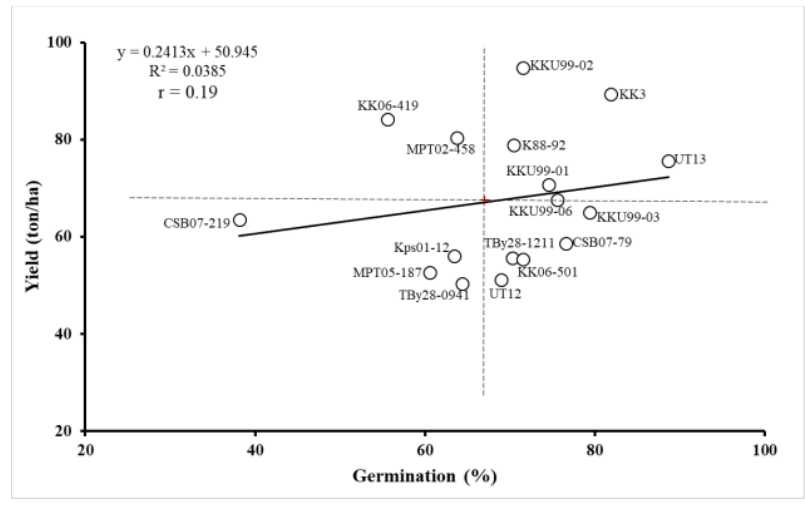

Figure 3 Relationship between germination percentage and cane yield of 17 sugarcane genotypes.

The sugarcane genotypes with high cane yield such as KKU99-02, KK3, K88-92, UT13 and KKU99-01 were associated with high germination percentage, whereas the sugarcane genotypes with low cane yield such as KK06-501 and CSB07-219 were associated with low germination percentage. The data also indicated that some sugarcane genotypes such as KK06-419 and MPT02-458 with high cane yield had intermediate germination percentage but the genotypes such as KK06-501 and CSB07219 with extremely low germination percentage did not have high yield.

The relationships between germination percentage and cane yield is presented in Figure. 3. The correlation between germination percentage and cane yield was not significant. However, the relationship between these traits was positive although it was low $(r=0.19)$. Germination of new plants from old plants is a critical event in sugarcane to assure good crop establishment and cane yield [12]. In this study the association of these traits was positive, indicating that germination percentage could contribute to cane yield for some extent. The associations of these traits was not strong could be possibly due to the effects of various factors that affect germination and cane yield.

Environmental factors greatly affect the ratooning ability and yield of ratoon crop [13,14]. The germinating bud is initially dependent on the nutrients and water in the set, and thereafter, it develops its own root system after about three weeks under proper conditions [15]. 
Soil water is also an important factor affecting germination of sugarcane. In Nigeria, the date of first irrigation after planting significantly affected sprouting percentage, and the best sprouting was obtained when sets were irrigated at planting [16]. Application superabsorbent polymer into the sandy soil to improve soil moisture content could increase germination and early growth of sugarcane [17].

In this study, irrigation was not available and the germination of the crop was dependent solely on stored soil water, and the authors evaluated the responses of sugarcane genotypes to the drought period at early growth phases of the second ratoon crop.

Sugarcane genotypes responded differently to soil moisture deficit for ratooning ability during drought period. UT13, KK3, KKU99-03, CSB07-79, KKU99-06, KKU99-01, KKU99-02, K88-92, TBy281211 and UT12 had high ratooning ability as indicated by high germination percentage in the second ratoon crop, whereas KKU99-02, KK3, K88-92, UT13 and KKU99-01 had high ratooning ability based on higher germination percentage and cane yield. Cane yield is a complex trait and, consequently, selection for can yield was generally done on the basis of yield components such as stalk number, stalk diameter, stalk length and single stalk weight. Effects of these traits on cane yield have been previously studied in the spring crop [18-20].

\subsection{Root length density}

Study of whole root systems under field conditions is difficult, and this might be possible only in greenhouse. Study of root length density using soil core method has been use to study roots of several crops under field conditions [21]. In this study, root length density was studied at two positions between rows and between plants in row and at 90 and $270 \mathrm{DAH}$. At the sampling times, the auger method was divided into five layers at $20 \mathrm{~cm}$ intervals and later the two upper layers were combined into one layer and three lower layer were combined into one layers because low recovery of the roots. The questions are that there are the variations in root length density in these sugarcane genotypes and which position of root length density is more informative.

Root length density was evaluated two times at 90 days after harvest (DAH) and 270 DAH at two positions between plants and between rows and at two soil depths at 0-40 cm and 40-100 cm (Table 2). Sugarcane genotypes were significantly different $(\mathrm{P} \leq 0.05)$ for root length density at both soil depths, positions of sampling and sampling times. At $90 \mathrm{DAH}$, root length density between plants at $0-40 \mathrm{~cm}(1.16 \mathrm{~cm})$ was higher than at $40-100 \mathrm{~cm}(0.24 \mathrm{~cm})$. Similarly, at $270 \mathrm{DAH}$, root length density between plants at 0-40 cm $(2.29 \mathrm{~cm})$ was also higher than at $40-100 \mathrm{~cm}(0.28 \mathrm{~cm})$. Root length densities between rows at 90 DAH were $0.18 \mathrm{~cm}$ for soil depth of $0-40 \mathrm{~cm}$ and $0.21 \mathrm{~cm}$ for soil depth of 40-100 cm, which were much lower than those between plants. Root length densities between rows at 270 DAH were $0.47 \mathrm{~cm}$ for soil depth of $0-40 \mathrm{~cm}$ and $0.21 \mathrm{~cm}$ for soil depth of $40-100$ $\mathrm{cm}$, which were lower than those between plants for root length densities at the soil depth of $0-40 \mathrm{~cm}$ and $40-100 \mathrm{~cm}$.

At 90 days after harvest, root length densities between plants at soil depth of $0-40 \mathrm{~cm}$ ranged from $0.24 \mathrm{~cm}$ in KK06-419 to $1.73 \mathrm{~cm}$ in UT13, whereas root length densities at soil depth of 40-100 $\mathrm{cm}$ ranged from $0.10 \mathrm{~cm}$ in UT13 to $0.40 \mathrm{~cm}$ in KKU99-06. The sugarcane genotypes with high root length density at the soil depth of 0-40 cm were KK3, K88-92, UT13, KKU99-06, KKU99-03, Kps01-12, TBy28-1211, KK06-501 and TBy28-0941, whereas the sugarcane genotypes with high root length density at the soil depth of 40-100 cm were KKU99-06, Kps01-12 and UT12. KKU99-06 and Kps01-12 had high root length density at both soil layers of 0-40 and 40-100 cm.

Table 2 Root length density in 17 sugarcane genotypes on positioned between plants and between rows at the 90 and 270 days after harvest in upper soil layer $(0-40 \mathrm{~cm})$ and lower soil layer $(40-100$ $\mathrm{cm})$.

\begin{tabular}{ccccc}
\hline Genotype & $\begin{array}{c}\mathrm{RLD}\left(\mathrm{cm} / \mathrm{cm}^{3}\right) \text { between } \\
\text { plantsat90DAH }\end{array}$ & $\begin{array}{c}\mathrm{RLD}\left(\mathrm{cm}^{2} / \mathrm{cm}^{3}\right) \\
\text { between } \\
\text { rowsat90DAH }\end{array}$ & $\begin{array}{c}\mathrm{RLD}\left(\mathrm{cm} / \mathrm{cm}^{3}\right) \text { between } \\
\text { plantsat270DAH }\end{array}$ & $\begin{array}{c}\mathrm{RLD}\left(\mathrm{cm}^{3} / \mathrm{cm}^{3}\right) \text { between } \\
\text { rowsat270DAH }\end{array}$ \\
\hline
\end{tabular}




\begin{tabular}{|c|c|c|c|c|c|c|c|c|}
\hline & $\begin{array}{l}\text { Upper } \\
(0-40 \mathrm{~cm})\end{array}$ & $\begin{array}{c}\text { Lower } \\
(40-100 \\
\mathrm{cm})\end{array}$ & $\begin{array}{c}\text { Upper } \\
(0-40 \\
\mathrm{cm})\end{array}$ & $\begin{array}{c}\text { Lower } \\
(40-100 \\
\mathrm{cm})\end{array}$ & $\begin{array}{l}\text { Upper } \\
(0-40 \mathrm{~cm})\end{array}$ & $\begin{array}{c}\text { Lower } \\
(40-100 \\
\mathrm{cm})\end{array}$ & $\begin{array}{l}\text { Upper } \\
(0-40 \mathrm{~cm})\end{array}$ & $\begin{array}{c}\text { Lower } \\
(40-100 \\
\mathrm{cm})\end{array}$ \\
\hline $\begin{array}{c}\text { KKU99- } \\
02\end{array}$ & 0.39 de & $0.22^{\mathrm{d}-\mathrm{g}}$ & $0.27^{\mathrm{cd}}$ & $0.21^{\text {def }}$ & $1.83^{\mathrm{d}-\mathrm{g}}$ & $0.49^{a}$ & $0.65^{\mathrm{b}}$ & $0.27^{\mathrm{cd}}$ \\
\hline KK3 & $1.60^{\mathrm{a}}$ & $0.24^{\text {def }}$ & $0.21^{\mathrm{de}}$ & $0.23^{\mathrm{c}-\mathrm{f}}$ & $2.54^{\text {be }}$ & $0.24^{\mathrm{e} h}$ & $0.27^{\mathrm{ef}}$ & $0.13^{\text {gh }}$ \\
\hline $\begin{array}{c}\text { KK06- } \\
419\end{array}$ & $0.24^{\mathrm{e}}$ & $0.28^{\text {be }}$ & $0.36^{\mathrm{b}}$ & $0.23^{\mathrm{cf}}$ & $3.49^{a}$ & $0.22^{\mathrm{eh}}$ & $1.08^{\mathrm{a}}$ & $0.42^{\mathrm{a}}$ \\
\hline $\begin{array}{c}\text { МРТ02- } \\
458\end{array}$ & $0.89 \mathrm{bc}$ & $0.22^{\text {efg }}$ & $0.06^{\text {gh }}$ & $0.25^{\mathrm{a}-\mathrm{d}}$ & $1.95^{\mathrm{d}-\mathrm{g}}$ & $0.27^{\mathrm{ef}}$ & $0.21^{\mathrm{fg}}$ & $0.21^{\text {def }}$ \\
\hline K88-92 & $1.46^{\mathrm{a}}$ & $0.19 \mathrm{fg}$ & $0.07^{\text {gh }}$ & $0.31^{\mathrm{ab}}$ & $2.28^{\mathrm{def}}$ & $0.28^{\text {def }}$ & $0.29 \mathrm{def}$ & $0.30^{\mathrm{bc}}$ \\
\hline UT13 & $1.73^{a}$ & $0.10^{\mathrm{h}}$ & $0.58^{a}$ & $0.23^{\mathrm{c} f}$ & $1.59^{\text {efg }}$ & $0.23^{\mathrm{eh}}$ & $0.63^{b}$ & 0.14 gh \\
\hline $\begin{array}{c}\text { KKU99- } \\
01\end{array}$ & $0.64^{\mathrm{cd}}$ & $0.22^{\mathrm{efg}}$ & $0.27^{\mathrm{cd}}$ & $0.29 \mathrm{abc}$ & $1.84^{\mathrm{d}-\mathrm{g}}$ & $0.27^{\text {def }}$ & $0.12^{g}$ & $0.17^{\text {efg }}$ \\
\hline $\begin{array}{c}\text { KKU99- } \\
06\end{array}$ & $1.61^{\mathrm{a}}$ & $0.40^{\mathrm{a}}$ & $0.16^{\mathrm{ef}}$ & $0.19 \mathrm{def}$ & $3.43^{\mathrm{ab}}$ & $0.15^{\mathrm{h}}$ & $0.42^{\mathrm{cd}}$ & $0.28^{\mathrm{cd}}$ \\
\hline $\begin{array}{c}\text { KKU99- } \\
03\end{array}$ & $1.51^{\mathrm{a}}$ & $0.18^{\text {fgh }}$ & $0.15^{\text {ef }}$ & $0.31^{\mathrm{ab}}$ & $2.48 b-e$ & $0.24^{\mathrm{eh}}$ & $0.74^{b}$ & $0.16^{\mathrm{eh}}$ \\
\hline $\begin{array}{c}\text { CSB07- } \\
219\end{array}$ & $0.58^{\text {cde }}$ & $0.16^{\text {gh }}$ & $0.13^{\mathrm{efg}}$ & $0.10^{\text {gh }}$ & $2.70^{a-d}$ & $0.26^{\mathrm{efg}}$ & $0.12^{g}$ & $0.10^{g h}$ \\
\hline CSB07-79 & $0.89^{b c}$ & $0.29^{b c d}$ & $0.01^{\mathrm{h}}$ & $0.18^{\mathrm{ef}}$ & $1.35^{\mathrm{fg}}$ & $0.32^{\text {cde }}$ & $0.21^{\mathrm{fg}}$ & $0.29^{b c}$ \\
\hline Kps01-12 & $1.59^{a}$ & $0.35^{\mathrm{ab}}$ & $0.29 b c$ & $0.32^{\mathrm{a}}$ & $1.16 \mathrm{~g}$ & $0.21_{\text {fgh }}$ & $0.74^{\mathrm{b}}$ & $0.22^{\text {de }}$ \\
\hline $\begin{array}{c}\text { TBy28- } \\
1211\end{array}$ & $1.55^{\mathrm{a}}$ & $0.26^{\mathrm{c}-\mathrm{f}}$ & 0.07 gh $^{-}$ & $0.10^{\text {gh }}$ & 2.39cde & $0.37 \mathrm{bcd}$ & $0.10 \mathrm{~g}$ & $0.15^{\mathrm{eh}}$ \\
\hline $\begin{array}{c}\text { KK06- } \\
501\end{array}$ & $1.53^{\mathrm{a}}$ & $0.25^{\mathrm{c}-\mathrm{f}}$ & $0.09^{\text {fgh }}$ & $0.17^{\text {fg }}$ & $2.33^{\text {cde }}$ & $0.38^{\mathrm{bc}}$ & $0.47^{c}$ & $0.15^{\text {fgh }}$ \\
\hline $\begin{array}{c}\text { МРT05- } \\
187\end{array}$ & $1.00^{\mathrm{b}}$ & $0.21^{\text {efg }}$ & $0.26^{\mathrm{cd}}$ & $0.20^{\text {def }}$ & $2.70^{a-d}$ & $0.47^{\mathrm{ab}}$ & $0.36^{\text {cde }}$ & $0.35^{\mathrm{b}}$ \\
\hline UT12 & $1.03^{b}$ & $0.32^{\mathrm{abc}}$ & $0.05^{\mathrm{h}}$ & $0.24^{\text {be }}$ & $1.72^{\mathrm{efg}}$ & $0.16^{\text {gh }}$ & $1.10^{\mathrm{a}}$ & $0.09^{h}$ \\
\hline $\begin{array}{c}\text { TBy28- } \\
0941\end{array}$ & $1.54^{\mathrm{a}}$ & $0.11^{\mathrm{h}}$ & $0.09^{\text {fgh }}$ & $0.07 \mathrm{~h}$ & $3.24^{\mathrm{abc}}$ & $0.18^{\text {fgh }}$ & $0.44^{c}$ & $0.16^{\mathrm{eh}}$ \\
\hline Mean & 1.16 & 0.24 & 0.18 & 0.21 & 2.29 & 0.28 & 0.47 & 0.21 \\
\hline F-test & $* *$ & $* *$ & $* *$ & $* *$ & $* *$ & $* *$ & $* *$ & $* *$ \\
\hline
\end{tabular}

** significant at $\mathrm{p} \leq 0.01$. Mean in the same column followed by the same letters are not significant different at $\mathrm{P} \leq 0.05$ by LSD

At 90 days after harvest, root length densities between rows at the soil layer of $0-40 \mathrm{~cm}$ ranged from $0.01 \mathrm{~cm}$ in CSB07-79 to $0.58 \mathrm{~cm}$ in UT13, whereas root length densities at the soil layer of 40-100 $\mathrm{cm}$ ranged from $0.07 \mathrm{~cm}$ in TBy28-0941 to $0.32 \mathrm{~cm}$ in Kps01-12. UT13 had high root length density at the soil layer of 0-40 cm, and MPT02-458, KKU99-03 and Kps01-12 had high root length density at soil layer of 40-100 cm. No sugarcane genotype showed high root length density at both soil layers.

At 270 days after harvest, root length densities between plants at the soil layer of $0-40 \mathrm{~cm}$ ranged from $1.16 \mathrm{~cm}$ in Kps01-12 to $3.49 \mathrm{~cm}$ in KK06-419, whereas root length densities at the soil layer of 40$100 \mathrm{~cm}$ ranged from $0.15 \mathrm{~cm}$ in KKU99-06 to $0.49 \mathrm{~cm}$ in KKU99-02. The sugarcane genotypes with high root length density at soil layer of 0-40 cm were KK06-419, KKU99-06, CSB07-219, MPT05-187 and TBy28-0941, whereas the sugarcane genotypes with high root length density at soil layer of 40$1400 \mathrm{~cm}$ were and KK06-419 and MPT05-187. MPT05-187 had high root length density at both soil layers of 0-40 and 40-100 cm.

At 270 days after harvest, root length densities between rows at the soil layer of $0-40 \mathrm{~cm}$ ranged from $0.10 \mathrm{~cm}$ in TBy28-1211 to $4.10 \mathrm{~cm}$ in UT12, whereas root length density at the soil layer of 40$100 \mathrm{~cm}$ ranged from $0.09 \mathrm{~cm}$ in UT12 to $0.42 \mathrm{~cm}$ in KK06-419. The sugarcane genotypes with high root length density at soil layer of 0-40 cm were KK06-419 and UT12. The sugarcane genotype (KK06-419) with high root length density at soil layer of $0-40 \mathrm{~cm}$ also In this study, variations in root length 
density were found in upper soil layers and lower soil layers at two positions and at 90 and $270 \mathrm{DAH}$. Root length density at the position between rows was much lower than the position between plants with in rows possibly due to the plants in the rows were much closer than the plants between rows. However, root length density at the position between rows was still useful.

Roots provide anchorage and facilitate acquisition of water and nutrients from the soil [22]. Sugarcane is a deep rooted crop owing to its long growth cycle and longevity of the root system through multiple rotations compared to other crops. Root system reaches to a depth of 1.5 meters and even 6 meters [4]. However, drought conditions had been reported to increase root system for seeking over water from the inadequate soil moisture environment sources [23].

In this study, sugarcane genotypes under drought stress condition had high root length density in lower soil layers at the position between plants and at the position between rows. KK3, K88-92 and UT13 showed high root length density in upper soil layers at the position between plants. UT13 had high in upper soil layer at the position between rows, whereas K88-92 and KKU99-01 showed high RLD in lower soil layers.

Deep rooting is a complex trait consisting of root growth angle and maximum root length [24,25]. Phenotypic variation in the root growth angle and root length density at the position between plants has been found to steep and near-vertical root angle [26]. Moreover, root length density at the position between rows has been found to near-horizontal root angle. Root growth angle determines whether a plant develops a shallow or deep root system.

\subsection{Root distribution patterns}

Drought may modify root growth of sugarcane and sugarcane genotypes may respond differently for root growth. The sugarcane genotypes were classified into three main groups for each evaluation time at $90 \mathrm{DAH}$ and $270 \mathrm{DAH}$ based on root distribution patterns of root length density at two positions between rows and between plants within row (Figure 4, 5). Each group has two subgroups, therefore, there were six main groups and 12 sub-groups altogether.

At $90 \mathrm{DAH}$, ten sugarcane genotypes consisting of TBy28-1211, K88-92, KKU99-03, TBy28-0941, KK06-501, UT12, KKU99-06, KK3, Kps01-12 and UT13 were classified into group 1, which was characterized by high root length density in the upper soil layers and low root length density in the lower soil layers at the position between plants (Figure 4). The sub-group 1.1 had seven sugarcane genotypes consisting of TBy28-1211, K88-92, KKU99-03, TBy28-0941, KK06-501, UT12, and KKU9906, whereas the sub-group 1.2 had three sugarcane genotypes including KK3, Kps01-12 and UT13. The sub-group 1.1 had low root length density in the upper soil layers and high root length density in the lower soil layers at the position between rows, whereas the sub-group 1.2 had high root length density in the upper soil layers and high root length density in the lower soil layers at the position between rows.

Group 2 had four sugarcane genotypes consisting of CSB07-79, CSB07-219, MPT02-458 and KKU99-01. The genotypes in this group had high root length density in the upper soil layers and in the lower soil layers at the position between plants. CSB07-79, CSB07-219 and MPT02-458 formed the groups 2.1 as they had low root length density in the upper soil layers and high root length density in the lower soil layers at the position between rows, and KKU99-01 was classified into the group 2.2 as they had high root length density in the upper soil layers and high root length density in the lower soil layers at the position between rows.

Group 3 had three sugarcane genotypes consisting of MPT05-187, KK06-419 and KKU99-02. The sugarcane genotypes in this group had high root length density in the upper soil layers and in the lower soil layers at the position between rows. KK06-419 and KKU99-02 were classified into subgroup 3.1 because its low root length density in the upper soil layers and high root length density in the lower soil layers at the position between plants, whereas MPT05-187 had low root length density in the upper soil layers and in the lower soil layers at the position between plants. 


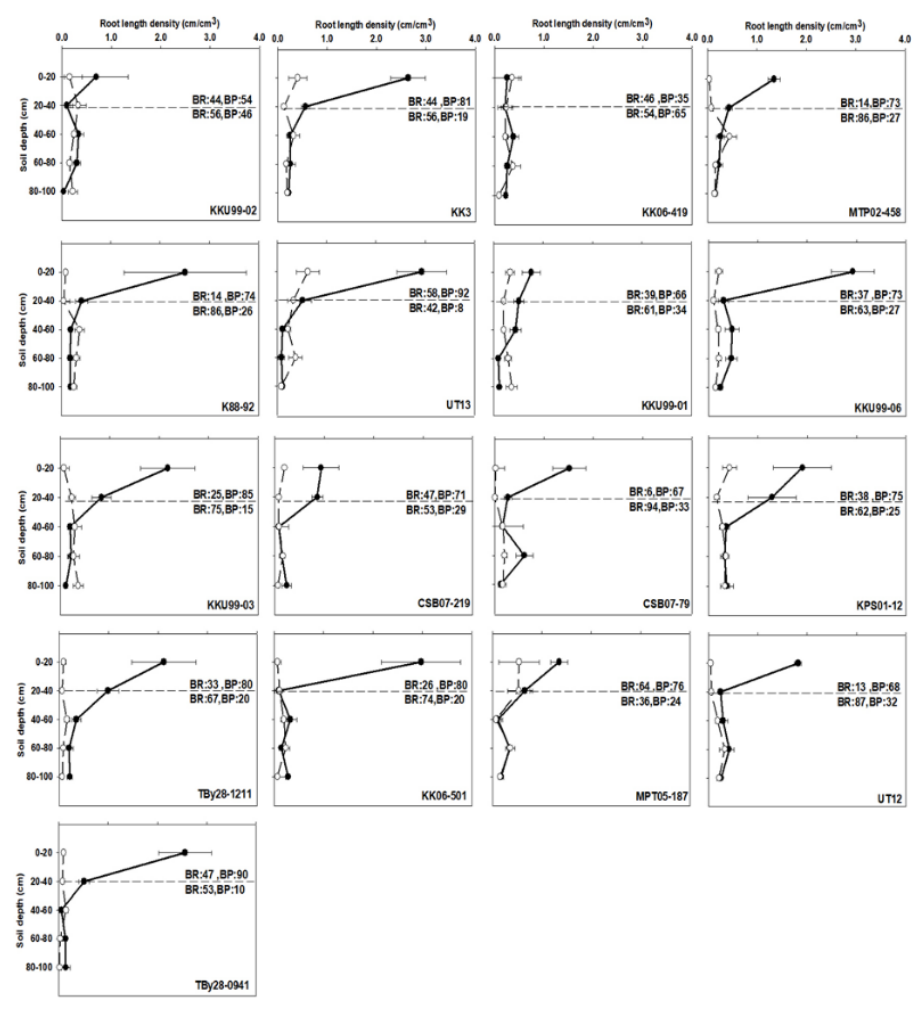

Figure 4 Root length density of 17 sugarcane genotypes in five soil layers at $20 \mathrm{~cm}$ intervals $(8-40 \mathrm{~cm}$ for uppegsoil layers and 40-100 cm for lower soil layers) evaluated at two positions between plant (BP) ( ) and between row (BR) ( ) at the 90 days after harvest.

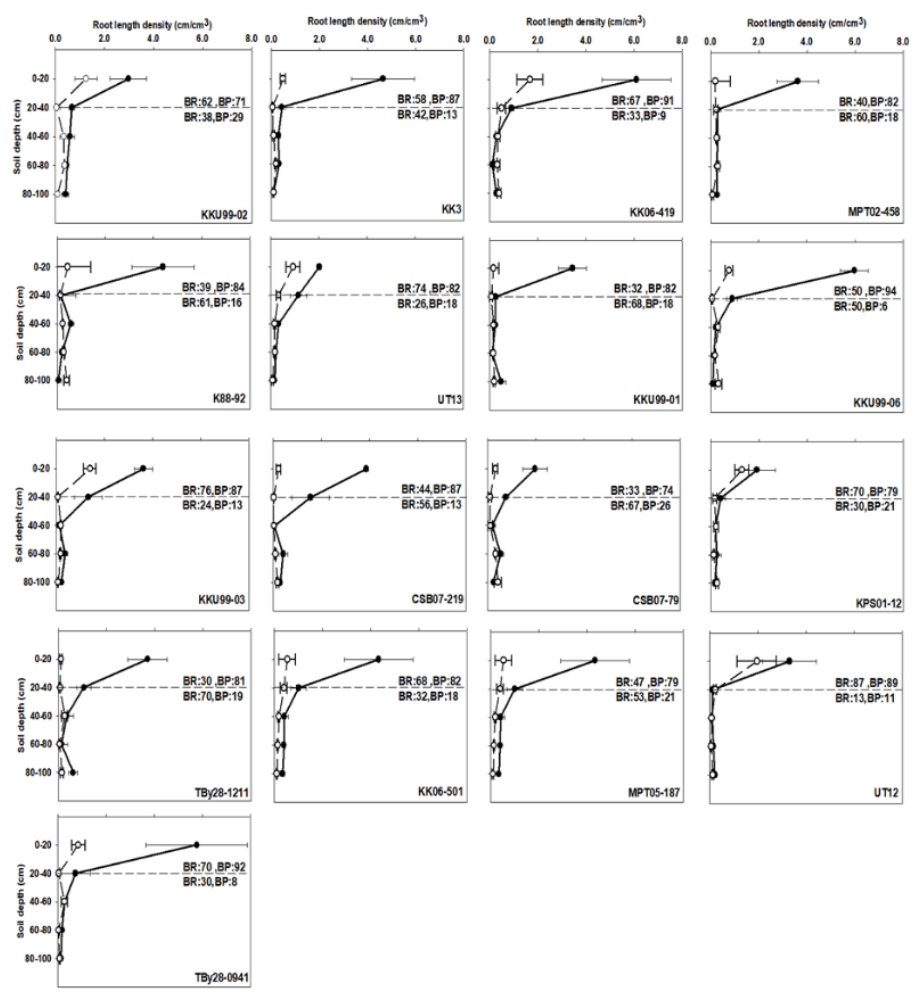


Figure 5 Root length density of 17 sugarcane genotypes in five soil layers at $20 \mathrm{~cm}$ intervals $(0-40 \mathrm{~cm}$ for upper soil layers and $40-100 \mathrm{~cm}$ for lower soil layers) evaluated at two positions betwe plant (BP) ( 9 and between row (BR) ( ) at the 270 days after harvest.

At 270 DAH, eight sugarcane genotypes consisting of TBy28-0941, KK06-501, MPT05-187, K8892, CSB07-219, KK3, KKU99-06 and KK06-419 were classified into group 1 (Figure 5). The sub-group 1.1 had six sugarcane genotypes consisting of TBy28-0941, KK06-501, MPT05-187, K88-92, CSB07-219 and KK3, whereas the sub-group 1.2 had two sugarcane genotypes including KKU99-06 and KK06419. The sub-group 1.1 had high root length density in the upper soil layers and low root length density in the lower soil layers at the position between plants, whereas, had low root length density in the upper soil layers and high root length density in the lower soil layers at the position between rows. The sub-group 1.2 had high root length density in the upper soil layers and high root length density in the lower soil layers at the position between plants and position between rows.

Group 2 had six sugarcane genotypes consisting of TBy28-1211, MPT02-458, KKU99-01, UT12, KKU99-02 and KKU99-03. The genotypes in this group had high root length density in the upper soil layers and low root length density in the lower soil layers at the position between plants. TBy28-1211, MPT02-458 and KKU99-01 formed the groups 2.1 as they had low root length density in the upper soil layers and lower soil layers at the position between rows. UT12, KKU99-02 and KKU99-03 were classified into the group 2.2 as they had high root length density in the upper soil layers and low root length density in the lower soil layers at the position between rows.

Group 3 had three sugarcane genotypes consisting of UT13, CSB07-79 and Kps01-12. The sugarcane genotypes in this group had high root length density in the upper soil layers and low root length density in the lower soil layers at the position between rows. UT13 and CSB07-79 were classified into sub-group 3.1 because its low root length density in the upper soil layers and high root length density in the lower soil layers at the position between plants, whereas Kps01-12 had low root length density in the upper soil layers and in the lower soil layers at the position between plants.

In this study, the well-watered control was not available. Under well-water conditions, root density was high in the upper soil layers. However, under drought conditions, plants increased root systems to take up more water from the inadequate soil moisture environments [23]. According to [27] drought could modify root growth to water uptake to meet the demand of the plant.

In this study, sugarcane genotypes were significantly different for germination percentage. Germination and development of sugarcane were closely related to soil moisture [28]. KKU99-06 showed high root length density at both soil layers of 0-40 and 40-100 $\mathrm{cm}$ under drought (at $90 \mathrm{DAH}$ ). The results indicated high root length density and good root distribution under drought supported germination.

Drought limits growth and physiological processes and, therefore, it reduces yield of sugarcane $[7,29]$ and plant height is most severely affected by drought [30]. Yield loss by drought would be as high as 60 percent [1].

Root is an important plant part that takes up nutrients and water to shoot and it is directly related to yield. Sugarcane genotypes might have drought tolerant mechanisms to cope with a water limited environments by maintaining high water status and investing more assimilate proportion for supplying root system during drought stress. The maintenance of high water uptake under drought stress might be assisted by improvement of root/shoot ratio, and the drought resistant cultivars are able to maintain high root/shoot ratio under drought [31].

\subsection{Physiological traits related to drought resistance}

SPAD chlorophyll meter reading (SCMR), chlorophyll fluorescence and relative water content were evaluated at 90, 180 and $270 \mathrm{DAH}$, whereas specific leaf area and stomatal conductance were evaluated at 180 and $270 \mathrm{DAH}$. Sugarcane genotypes were significantly different $(\mathrm{P} \leq 0.05)$ for SCMR at 180 and $270 \mathrm{DAH}$, chlorophyll fluorescence at 90 and $180 \mathrm{DAH}$ and relative water content at 90 DAH (Table 3). KKU99-02, CSB07-79, TBy28-1211 and MPT05-187 had the highest SCMR at 180 DAH, and TBy28-1211 also had the highest SCMR at 270 DAH. TBy28-1211 and UT12 had the highest chlorophyll fluorescence at 90 DAH, whereas KK06-419, MPT02-458, K88-92, UT13, KKU99-01, 
KKU99-06, TBy28-1211, Kps01-12, TBy28-1211 and MPT05-187 had the highest chlorophyll fluorescence at $270 \mathrm{DAH}$.

Relative water content at $90 \mathrm{DAH}(96.20 \%)$ was lower than at 180 and $270 \mathrm{DAH}$ (98.26 and 96.61, respectively). Although sugarcane genotypes were significantly different for relative water content at $90 \mathrm{DAH}$, the differences were rather small and most sugarcane genotypes were similar except for MPT02-458, Kps01-12 and KK06-501, which had the lowest relative water content.

Sugarcane genotypes were significantly different $(\leq \mathrm{P} 0.05)$ for specific leaf area at 180 and 270 DAH and stomatal conductance at 180 and 270 DAH (Table 4). Specific leaf area at 180 DAH (82.99 $\left.\mathrm{cm}^{2} / \mathrm{g}\right)$ was higher than at $270 \mathrm{DAH}\left(66.47 \mathrm{~cm}^{2} / \mathrm{g}\right)$, whereas stomatal conductance at $180 \mathrm{DAH}(304.32$ $\left.\mu \mathrm{m}^{2} / \mathrm{s}\right)$ was lower than at $270 \mathrm{DAT}\left(338.20 \mu \mathrm{m}^{2} / \mathrm{s}\right)$. The genotypes with low specific leaf area are preferable as they show thicker leaves. KK3, K88-92, CSB07-219, CSB07-219, KK06-501, MPT05-187 and UT12 had the lowest specific leaf area at 180 DAH, KK3, KK06-419, MPT02-458, K88-92, Kps0112, UT12 and TBy28-0941 had the lowest specific leaf area at 270 DAH. KK3, K88-92 and K88-92 had consistently high specific leaf area across sampling dates.

The sugarcane genotypes with high values are preferable. KK3, KK06-419, MPT02-458, UT13, KKU99-01, KKU99-06, KKU99-03, Kps01-12 and TBy28-1211 had the highest stomatal conductance at 180 DAH, and KK06-419, Kps01-12, TBy28-1211 and MPT05-187 had high specific leaf area at 270 DAH, KK06-419, Kps01-12 and TBy28-1211 showed high stomatal conductance at both 180 DAH and $270 \mathrm{DAH}$.

Table 3 SPAD chlorophyll meter reading (SCMR), Chlorophyll fluorescence and Relative water content (RWC) of the $2^{\text {nd }}$ ratoon cane in 17 sugarcane genotypes.

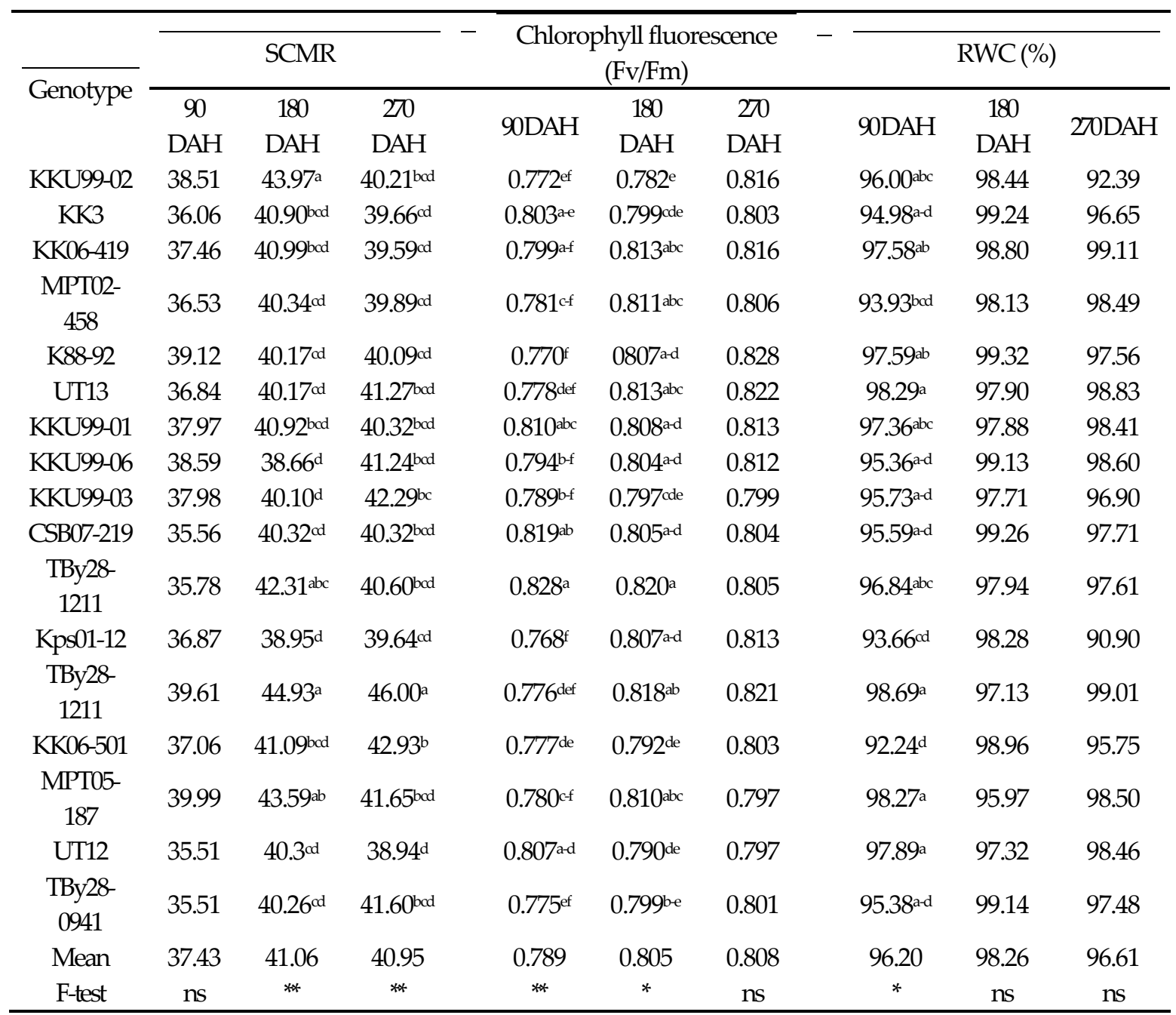

$\mathrm{ns},{ }^{*},{ }^{* *}$ non-significant and significant at $\mathrm{p} \leq 0.05$ and $\mathrm{p} \leq 0.01$, respectively. Mean in the same column followed by the same letters are not significant different at $\mathrm{P} \leq 0.05$ by LSD 
Table 4 Specific leaf area (SLA) and stomatal conductance of the second ratoon cane in 17 sugarcane genotypes.

\begin{tabular}{|c|c|c|c|c|}
\hline \multirow[t]{2}{*}{ Genotype } & \multicolumn{2}{|c|}{ Specific leaf area $\left(\mathrm{cm}^{2} / \mathrm{g}\right)$} & \multicolumn{2}{|c|}{ Stomatal conductance $\left(\mu \mathrm{m}^{2} / \mathrm{s}\right)$} \\
\hline & $180 \mathrm{DAH}$ & $270 \mathrm{DAH}$ & $180 \mathrm{DAH}$ & $270 \mathrm{DAH}$ \\
\hline KKU99-02 & $83.14^{\text {def }}$ & $66.58^{\mathrm{b}-\mathrm{e}}$ & $264.87^{\mathrm{ef}}$ & $354.78^{\mathrm{bcd}}$ \\
\hline KK3 & $62.99 \mathrm{~h}$ & $57.58^{\mathrm{ef}}$ & $358.05^{\mathrm{a}}$ & 316.20def \\
\hline KK06-419 & $91.30^{\mathrm{bcd}}$ & $55.37^{\mathrm{f}}$ & $330.10^{\mathrm{ab}}$ & $372.90^{\mathrm{ab}}$ \\
\hline МРТ02-458 & $98.12^{\mathrm{bc}}$ & $58.34^{\mathrm{ef}}$ & $318.73^{\mathrm{abc}}$ & $317.95^{\text {def }}$ \\
\hline K88-92 & $68.36^{\mathrm{h}}$ & $54.97^{f}$ & $258.33^{e f}$ & $272.48 \mathrm{~g}$ \\
\hline UT13 & $88.75^{\mathrm{b}-\mathrm{e}}$ & $69.13^{\mathrm{bcd}}$ & $317.15^{\mathrm{a}-\mathrm{d}}$ & $326.33^{c-f}$ \\
\hline KKU99-01 & $85.60^{c-f}$ & $74.46^{\mathrm{b}}$ & $336.68^{\mathrm{ab}}$ & $356.48^{\mathrm{bcd}}$ \\
\hline KKU99-06 & $101.29 \mathrm{~b}$ & $69.46^{\mathrm{bcd}}$ & $353.28^{a}$ & $324.13^{\mathrm{c}-\mathrm{f}}$ \\
\hline KKU99-03 & $119.76^{a}$ & $71.45^{\mathrm{bc}}$ & $322.07 \mathrm{ab}$ & $327.38^{\mathrm{c}-\mathrm{f}}$ \\
\hline CSB07-219 & $65.08^{\mathrm{h}}$ & $68.75^{\mathrm{bcd}}$ & $251.40^{f}$ & $355.33^{\mathrm{bcd}}$ \\
\hline CSB07-219 & $65.13^{\mathrm{h}}$ & $67.41^{\mathrm{b}-\mathrm{e}}$ & $269.68^{\mathrm{ef}}$ & $342.68^{\text {b-e }}$ \\
\hline Kps01-12 & $84.95^{\mathrm{c}-\mathrm{f}}$ & $61.11^{\text {def }}$ & $353.47^{a}$ & $380.00^{\mathrm{ab}}$ \\
\hline TBy28-1211 & $82.57^{\mathrm{d}-\mathrm{g}}$ & $71.27 \mathrm{bc}$ & $343.20^{\mathrm{ab}}$ & $365.75^{\mathrm{abc}}$ \\
\hline KK06-501 & $75.58^{\mathrm{e}-\mathrm{h}}$ & $72.52^{\mathrm{b}}$ & $246.00^{f}$ & $337.10^{\mathrm{b}-\mathrm{e}}$ \\
\hline МРТ05-187 & $73.87^{\text {fgh }}$ & $84.96^{\mathrm{a}}$ & $272.83^{\mathrm{def}}$ & $408.28^{a}$ \\
\hline K88-92 & $68.88 \mathrm{gh}$ & $64.53^{b-f}$ & $275.15^{\mathrm{c}-\mathrm{f}}$ & $291.03^{f g}$ \\
\hline ТВу28-0941 & $95.55^{\mathrm{bcd}}$ & $61.96^{\mathrm{c}-\mathrm{f}}$ & $302.50^{\mathrm{b}-\mathrm{e}}$ & $300.68^{\text {efg }}$ \\
\hline Mean & 82.99 & 66.47 & 304.32 & 338.20 \\
\hline F-test & $* *$ & $* *$ & $* *$ & $* *$ \\
\hline
\end{tabular}

** significant at $\mathrm{p} \leq 0.01$. Mean in the same column followed by the same letters are not significant different at $\mathrm{P} \leq 0.05$ by LSD

In general, drought reduces soil water potential, leaf water potential $[32,33]$ and photosynthetic efficiency of photosystem II [7]. Drought also reduces relative water content [7,34] stomata conductance [35] photosynthetic rate [36-38] and PSII photochemical efficiency [35].

In this study, KK3, KK06-419 and KKU99-01 increased chlorophyll fluorescence and relative water content under drought stress period. They might have drought tolerance mechanisms to maintain high water status under drought. Maintenance of high water status was possibly due to the ability of root to mine more water under drought [39].

In this study, sugarcane genotypes were not significantly different for SCMR at $90 \mathrm{DAH}$. In previous study, early season drought significantly reduced SCMR in sugarcane [40]. According to [41] SCMR is an indicator of the photo-synthetically active light-transmittance characteristics of leaf, which is dependent on the unit number of chlorophyll per unit leaf area (chlorophyll density). SCMR was also closely related to chlorophyll content [42] and chlorophyll density [43]. The differences in the results among different studies might be due to the differences in plant ages, plant genotypes and drought duration and severity.

KK3 and K88-92 had low specific leaf area at $180 \mathrm{DAH}$, which was the period that the crop was recovered from drought, indicating that this genotype had thicker leaves. Thicker leaves usually have higher chlorophyll per unit leaf area and hence had a greater photosynthetic capacity.

KK06-419 showed high stomatal conductance after recovery period. Stomatal conductance of sugarcane had been controlled by roots, and might also involve in chemical signal [44]. In sugarcane, drought-tolerant genotypes could maintain high relative water content under drought [45]. KKU9902, KK3, KK06-419, K88-92, UT13 and KKU99-01 had high relative water content under drought. In sugarcane, the cultivars with drought tolerance had higher relative water content and stomatal conductance than did the susceptible cultivars [46].

Enhanced root length in the lower soil layers enables plants to better extract available soil moisture from soil profile [23,47]. Root system of plant responds to soil water both water limited soil and water abundant soil. Root growth deep into the lower soil results in the increase in relative water 
content of about 40-51\% [48]. [49] reported that roots and physiological responses such as root length, chlorophyll fluorescence and stomatal conductance at stressed period were important factors contributing to sugarcane biomass yield.

\subsection{Correlations among traits}

The correlation coefficients of root length density with cane yield and germination percentage were presented in Table 5. Most correlation coefficients were not statistically significant. However, significant correlation coefficients were observed for root length density between plants in upper soil layers at $90 \mathrm{DAH}$ and germination percentage $\left(0.36^{* *}\right)$, root length density between plants in lower soil layers at $270 \mathrm{DAH}$ and germination percentage $\left(-0.32^{*}\right)$, root length density between rows in lower soil layers at $90 \mathrm{DAH}$ and cane yield $\left(0.35^{*}\right)$ and root length density between rows in lower soil layers at $270 \mathrm{DAH}$ and cane yield $\left(0.51^{* *}\right)$.

Root length density between plants at early growth phases (90 DAH) in the upper soil layers might be beneficial to germination percentage, whereas germinated plants may reduce root length density between plants at $270 \mathrm{DAH}$ in the lower soil layers. In contrast, germinated plants increased root length density between rows at 90 and $270 \mathrm{DAH}$ in the lower soil layers. The negative correlation of root length density between plants in lower soil layers at $270 \mathrm{DAH}$ and germination percentage might be due to competition for assimilates between shoots and roots. Where water is available in the surface layers of the soil following harvest, new shoots are sustained by new superficial roots, but that persistence of the old root system is critical to survival of the stool and growth of the ratoon crop during dry periods after harvest [50].

Table 5 Correlation coefficient ( $r$ ) of root length density (RLD) on cane yield and germination percentage of the $2^{\text {nd }}$ ratoon cane of 17 sugarcane genotypes.

\begin{tabular}{|c|c|c|}
\hline & Cane yield 1 & $\begin{array}{l}\text { Germination } \\
\text { percentage } 1\end{array}$ \\
\hline \multicolumn{3}{|l|}{ Root length density } \\
\hline \multicolumn{3}{|l|}{ Upper soil layer $(0-40 \mathrm{~cm})$} \\
\hline RLD between plants at $90 \mathrm{DAH}$ & -0.12 & $0.36^{* *}$ \\
\hline RLD between rows at $90 \mathrm{DAH}$ & 0.22 & 0.14 \\
\hline RLD between plants at $270 \mathrm{DAH}$ & 0.17 & -0.14 \\
\hline $\begin{array}{l}\text { RLD between rows at } 270 \mathrm{DAH} \\
\text { Lower soil layer }(40-100 \mathrm{~cm})\end{array}$ & -0.09 & -0.01 \\
\hline RLD between plants at $90 \mathrm{DAH}$ & 0.12 & -0.00 \\
\hline RLD between rows at $90 \mathrm{DAH}$ & $0.35^{*}$ & 0.12 \\
\hline RLD between plants at $270 \mathrm{DAH}$ & -0.00 & $-0.32^{*}$ \\
\hline RLD between rows at $270 \mathrm{DAH}$ & $0.51^{* *}$ & -0.12 \\
\hline \multicolumn{3}{|c|}{$\begin{array}{l}*,{ }^{* *} \text { significant at } 0.05 \text { and } 0.01 \text { probability level, respectively. }{ }^{1} \text { The data were calculated fr } \\
\text { treatment means with degree of freedom of } 67 \text {. }\end{array}$} \\
\hline \multicolumn{3}{|c|}{$\begin{array}{l}\text { Table } 6 \text { Correlation coefficients ( } \mathrm{r} \text { ) of physiological traits (SPAD chlorophyll meter reading (SCMR) } \\
\text { Chlorophyll fluorescence and Relative water content (RWC), specific leaf area (SLA) and stomata } \\
\text { conductance) on cane yield and germination percentage of the } 2^{\text {nd }} \text { ratoon cane of } 17 \text { sugarcan } \\
\text { genotypes. }\end{array}$} \\
\hline & Cane yield 1 & $\begin{array}{l}\text { Germination } \\
\text { percentage } 1\end{array}$ \\
\hline \multicolumn{3}{|l|}{ Physiological traits } \\
\hline Chlorophyll fluorescence & -0.01 & 0.05 \\
\hline RWC & 0.13 & $0.27^{*}$ \\
\hline SCMR & 0.21 & 0.21 \\
\hline At 180 DAH. & & \\
\hline
\end{tabular}




\begin{tabular}{ccc}
\hline Chlorophyll fluorescence & $0.44^{* *}$ & 0.27 \\
RWC & 0.06 & -0.07 \\
SCMR & 0.04 & -0.23 \\
SLA & 0.18 & 0.14 \\
Stomatal conductance & $0.36^{* *}$ & $0.45^{* *}$ \\
At 270 DAH. & \\
Chlorophyll fluorescence & 0.19 & -0.03 \\
RWC & 0.10 & 0.21 \\
SCMR & -0.07 & 0.01 \\
SLA & -0.26 & -0.05 \\
Stomatal conductance & 0.08 & -0.16 \\
*** significant at 0.05 and 0.01 probability level, respectively. 1The data were calculated from \\
treatment means with degree of freedom of 67. &
\end{tabular}

It is interesting to note here that root length density between rows in lower soil layers at 90 and 270 DAH supported can yield of sugarcane. These root distributions might be due to adaptation to drought and had benefits to sugarcane to take up more water in the lower soil layers. Row distance is an important factor affecting root distribution patterns of sugarcane [51]. Wide distance of rows may provide more soil moisture to the crop during water limited conditions.

Physiological traits that had significant correlations with germination percentage were relative water content at $90 \mathrm{DAH}\left(0.27^{*}\right)$ and stomatal conductance at $180 \mathrm{DAH}$, whereas physiological traits what had significant correlations with cane yield were chlorophyll fluorescence at $180 \mathrm{DAH}\left(0.44^{* *}\right)$ and stomatal conductance at $180 \mathrm{DAH}\left(0.36^{* *}\right)$ (Table 6). Physiological traits at $270 \mathrm{DAH}$ were not correlated with cane yield and germination percentage.

Soil moisture is important factor for germination of sugarcane as indicated by high correlation of germination and relative water content at $90 \mathrm{DAH}$. Germinated plants might then increase stomatal conductance and ultimately increase can yield. Stomatal and root hydraulic conductances are correlated in sugarcane, for both pot and field-grown crops, resulting in approximately homeostatic regulation of leaf water potential [4].

Chlorophyll fluorescence at $90 \mathrm{DAH}$ is also another trait that was related to yield at harvest, whereas all physiological traits at $270 \mathrm{DAH}$ were not related to germination percentage and cane yield. The significant correlation between chlorophyll fluorescence and cane yield is not surprising because this trait is related to photosynthesis [52]. Chlorophyll fluorescence might be useful as a surrogate trait for cane yield. Evaluation of physiological traits at $270 \mathrm{DAH}$ may be too late to find the significant relationships on cane yield.

\section{Conclusion}

The sugarcane genotypes were significantly different for germination percentage and cane yield, but the correlation between these traits were low although it was positive. The results indicated that reduction in germination percentage could lead to lower can yield. Selection of sugarcane genotypes with medium to high germination percentage should improve ratooning ability in these sugarcane population. The correlation between root length density and germination percentage indicated that root length density between plants at $90 \mathrm{DAH}$ in the upper soil layers might contribute to high germination percentage and root length density between rows at 90 and $270 \mathrm{DAH}$ in the lower soil layer might contribute to high cane yield.

Relative water content at $90 \mathrm{DAH}$ was significantly correlated with germination percentage, indicating that high water uptake of plants is important for high germination. Chlorophyll fluorescence and stomatal conductance were positively associated with germination percentage and cane yield, indicating that these traits contribute to cane yield for some extent.

\section{Acknowledgments}

The research project was funded by the Thailand Research Fund (TRF) (Grant No. RDG5850007 and RDG5950151) and the Northeast Thailand Cane and Sugar Research Center (NECS), Khon Kaen University 
(KKU). The acknowledgement is also extended to the manuscript preparation project of KKU and Thailand Research Fund (TRF).

\section{References}

1. Robertson, M.J.; Inman-Bamber, N.G.; Muchow, R.C.; Wood, A.W. Physiology and productivity of sugarcane with early and mid-season water deficit. Field Crops 1999, 64, 211-227.

2. Malik, K.B. Profitable cultivation of sugarcane. Pakistan: Directorate of Agricultural Information, Agriculture Department of Punjab, Lahore, Pakistan, 1997, pp. 49.

3. Singh, P.K.; Dey, P. Genetic variability in plant and ratoon of sugarcane genotypes grown under saline conditions. Indian Sugar 2002, 51, 725-727.

4. Smith, D.M.; Inman-Bamber, N.G.; Thorburn, P.J. Growth and function of the sugarcane root system. Field Crops Research 2005, 92, 169-183.

5. Laclau, P.B.; Laclau, J.P. Growth of the whole root system for a plant crop of sugarcane under rainfed and irrigated environments in Brazil. Field Crops Research 2009, 114, 351-360.

6. Gregory, P.J. Plant roots growth, activity and interaction with soil. Australia: Blackwell Publishing Asia, 550 Swanaston Street, Carlton, Victoria 3053, Australia, 2006.

7. Silva, M.D.A.; Jifon, J.L.; Da Silva, J.A.; Sharma, V. Use of physiological parameters as fast tools to screen for drought tolerance in sugarcane. Brazilian Journal of Plant Physiology 2007, 19, 193 201.

8. Silva, M.A.; Jifon, J.L.; Sharma, V.; Silva, J.A.G.; Caputo, M.M.; Damaj, M.B.; Guimara, E.R. Use of physiological parameters in screening drought tolerance in sugarcane genotypes. Sugar Tech 2011, 13, 191-197.

9. Santos, C.M.; Almeida Silva, M.; Lima,G.P.; Almeida Prado Bortolheiro, F.P.; Brunelli, M.C.; Holanda, L.A.; Oliver, R. Physiological changes associated with antioxidant enzymes in response to sugarcane tolerance to water deficit and rehydration. Sugar Tech 2015, 17, 291-304.

10. Watanabe, K.; Saensupo, S.; Na-iam, Y.; Klomsa-ard, P.; Sriroth, K. Effects of superabsorbent polymer on soil water sontent and sugarcane germination and early growth in sandy soil conditions. Sugar Tech 2018, 1-7.

11. Ford, K.E.; Gregory, P.J.; Gooding, M.J.; Pepler, S.Genotype and fungicide effects on late-season root growth of winter wheat. Plant Soil 2006, 284, 33-44.

12. Tomer, P. S. Better germination of sugar cane and high yield. Indian sugar, 1969.

13. Gomathi, R.; Rao, P.N.G.; Rakkiyappan, P.; Sundara, B.P.; Shiyamala, S. Physiological studies on ratoonability of sugarcane varieties under tropical Indian condition. American Journal of Plant Sciences 2013, 4, 274.

14. Shrivastava A.K.; Ghosh, A.K.; Agnihotri, V.P. Sugarcane ratoons. New Delhi: Oxford and I.B.H. Publishing Co. Pvt. Ltd., New Delhi, India, 1992, pp. 182.

15. Bull, T.A.; Glasziou, K.T. Sugarcane. In: EVANS, L.T. (Ed.). Crop Physiology. Cambridge: Cambridge University Press. 1975.

16. Abayomi, Y.A.; Etejere, E.O.; Fadayomi, O. Effect of stalk section, coverage depth and date of first irrigation on seedcane germination of two commercial sugarcane cultivars in Nigeria. Turrialba 1990, 40, 58-62.

17. Watanabe, K.; Saensupo, S.; Na-iam, Y.; Klomsa-ard, P.; Sriroth, K. Effects of superabsorbent polymer on soil water sontent and sugarcane germination and early growth in sandy soil conditions. Sugar Tech 2018, 1-7. 
18. Kang, M.S.; Sosa, O.; Miller, J.D. Path analyses for percent fiber and cane and sugar yield in sugarcane. Crop science 1989, 29, 1481-1483.

19. Milligan, S.B.; Gravois, K.A.; Bischoff, K.P.; Martin, F.A. Crop effects on genetic relationships among sugarcane traits. Crop Science 1990, 30, 927-931.

20. Singh, H.N.; Singh, S.B.; Chauhan, R.V.S.; Vishwakarma, R.S. Variability for yield and quality in sugarcane. Indian Journal of Agricultural Sciences 1983, 53, 786-789.

21. Samson, B. K.; Sinclair, T. R. Soil core and minirhizotron comparison for the determination of root length density. Plant and Soil 1994, 161, 225-232.

22. Lynch, J. Root architecture and plant productivity. Plant physiology 1995, 109, 7-13

23. Jongrungklanga, N.; Toomsana, B.; Vorasoota, N.; Jogloya, S.; Booteb, K.J.; Hoogenboomc, G.; Patanothaia, A. Drought tolerance mechanisms for yield responses to pre-flowering drought stress of peanut genotypes with different drought tolerant levels. Field Crops Research 2013, 144, 34-42.

24. Araki, H.; Morita, S.; Tatsumi, J.; Iijima, M. Physiol-morphological analysis on axile root growth in upland rice. Plant production science 2002, 5, 286-293.

25. Uga, Y.; Sugimoto, K.; Ogawa, S.; Rane, J.; Ishitani, M.; Hara, N.; Kitomi, Y.; Inukai, Y.; Ono, K.; Kanno, N.; Inoue, H.; Takehisa, H.; Motoyama, R.; Nagamura, Y.; Wu, J.; Matsumoto, T.; Takai, T.; Okuno, K.; Yano, M. Control of root system architecture by deeper rooting 1 increases rice yield under drought conditions. Nature genetics 2013, 45, 1097.

26. An, H.; Dong, H.; Wu, T.; Wang, Y.; Xu, X.; Zhang, X.; Han, Z. Root growth angle: An important trait that influences the deep rooting of apple rootstocks. Scientia Horticulturae 2017, 216, $256-$ 263.

27. Kato, Y.; Okami, M. Root morphology, hydraulic conductivity and plant water relations of highyielding rice grown under aerobic conditions. Annals of Botany 2011, 108, 575-583.

28. Moreira, D. R.; Cardoso, V. J. M. Effect of soil moisture content and the irrigation frequency on the sugarcane germination. Pesquisa Agropecuária Brasileira 1998, 721-729.

29. Zhang, M.Q.; Li, G.J.; Chen, R.K. Photosynthesis characteristics in eleven cultivars of sugarcane and their responses to water stress during the elongation stage. Proceedings - International Society of Sugar Cane Technologists 2001, 24, 642-643.

30. Silva, M.D.A.; Silva, J.A.G.D.; Enciso, J.; Sharma, V.; Jifon, J. Yield components as indicators of drought tolerance of sugarcane. Scientia Agricola 2008, 65, 620-627.

31. Jangpromma, N.; Thammasirirak, S.; Jaisil, P.; Songsri, P. Effects of drought and recovery from drought stress on above ground and root growth, and water use efficiency in sugarcane (Saccharum officinarum L.). Australian Journal of Crop Science 2012, 6, 1298-1304.

32. Steudle, E. Water uptake by roots: effects of water deficit. Journal of Experimental Botany 2000, 51, 1531-1542.

33. Liberato, M.A.R.; Gonçalves, J.F.D.C.; Chevreuil, L.R.; Junior, N.; da Rocha, A.; Fernandes, A.V. Santos Junior, U.M.D. Leaf water potential, gas exchange and chlorophyll a fluorescence in acariquara seedlings (Minquartia guianensis Aubl.) under water stress and recovery. Brazilian Journal of Plant Physiology 2006, 18, 315-323.

34. Lobato, A.K.S.; Oliveria Neto, C.F.; Costa, R.C.L; Santos Filho, B.G.; Cruz, F.J.R.; Laughinghouse, I.V. Biochemical and physiological behavior of Vigna unguiculata (L.) Walp. under water stress during the vegetative stage. Asian Journal of Plant Sciences 2008, 7, 44-49.

35. Zhao, D.; Glaz, B.; Comstock, J.C. Sugarcane response to water-deficit stress during early growth on organic and sand soils. American Journal of Agricultural and Biological Sciences 2010, 5, 403-414. 
36. Davies, W.J.; Wilkinson, S.; Loveys, B. Stomatal control by chemical signalling and the exploitation of this mechanism to increase water use efficiency in agriculture. New phytologist 2002, 153, 449-460.

37. Azevedo Neto, A.D.D.; Prisco, J.T.; Enéas-Filho, J.; Lacerda, C.F.D.; Silva, J.V. ; Costa, P.H.A.D.; Gomes-Filho, E. Effects of salt stress on plant growth, stomatal response and solute accumulation of different maize genotypes. Brazilian Journal of Plant Physiology 2004, 16, 31-38.

38. Smit, M.A.; Singels, A. The response of sugarcane canopy development to water stress. Field Crops Research 2006, 98, 91-97.

39. Turner, N.C. Adaptation to water deficits: a changing perspective. Functional Plant Biology 1986, 13, 175-190.

40. Jangpromma, N.; Songsri, P.; Thammasirirak, S.; Jaisil, P. Rapid assessment of chlorophyll content in sugarcane using a SPAD chlorophyll meter across different water stress conditions. Asian Journal of Plant Sciences 2010, 9, 368-374.

41. Richardson, A.D.; Duigan, S.P.; Berlyn, G.P. An evaluation of noninvasive methods to estimate foliar chlorophyll content. New phytologist 2002, 153, 185-194.

42. Akkasaeng, C.; Vorasoot, N.; Jogloy, S.; Patanotai, A. Relationship between SPAD readings and chlorophyll contents in leaves of peanut (Arachis hypogaea L.). Thai Journal of Agricultural Science 2003, 36, 279-284.

43. Arunyanark, A.; Jogloy, S.; Akkasaeng, C.; Vorasoot, N.; Kesmala, T.; Nageswara Rao, R.C.; Patanothai, A. Chlorophyll stability is an indicator of drought tolerance in peanut. Journal of Agronomy and Crop Science 2008, 194, 113-125.

44. Smith, J.P.; Lawn, R.J.; Nable, R.O. Investigations into the root: shoot relationship of sugarcane, and some implications for crop productivity in the presence of sub-optimal soil conditions. Proceedings of the Australian Society of Sugar Cane Technologists 1999, 21, 108-113.

45. Boutraa, T.; Akhkha, A.; Al-Shoaibi, A.A.; Alhejeli, A.M. Effect of water stress on growth and water use efficiency (WUE) of some wheat cultivars (Triticum durum) grown in Saudi Arabia. Journal of Taibah University for Science 2010, 3: 39-48.

46. Graça, J.P.D.; Rodrigues, F.A.; Farias, J.R.B.; Oliveira, M.C.N.D.; Hoffmann-Campo, C.B.; Zingaretti, S.M. Physiological parameters in sugarcane cultivars submitted to water deficit. Brazilian Journal of Plant Physiology 2010, 22, 189-197.

47. Songsri, P.; Jogloy, S.; Kesmala, T.; Vorasoot, N.; Akkasaeng, C.; Patanothai, A.; Holbrook, C.C. Response of reproductive characters of drought resistant peanut genotypes to drought. Asian Journal of Plant Sciences 2008, 7, 427-439.

48. Derner, J.D.; Polley, H.W.; Johnson, H.B.; Tischler, C.R. Root system response of $\mathrm{C}_{4}$ grass seedlings to $\mathrm{CO}_{2}$ and soil water. Plant and Soil 2001, 231, 97-104.

49. Khonghintaisong, J.; Songsri, P.; Toomsan, B.; Jongrungklang, N. Rooting and physiological trait responses to early drought stress of sugarcane cultivars. Sugar Tech 2018, 20, 396-406.

50. Glover, J. The behaviour of the root-system of sugarcane at and after harvest. Proc. S. Afr. Sugar Technol. Assoc 1968, 42, 133-135.

51. Azevedo, M. C. B. D.; Chopart, J. L.; Medina, C. D. C. Sugarcane root length density and distribution from root intersection counting on a trench-profile. Scientia Agricola 2011, 68, 94 101.

52. Krause, G.H.; Weis, E. Chlorophyll fluorescence and photosynthesis: The basics. Annual review of plant physiology and plant molecular biology 1991, 42, 313-49. 